\title{
Personality Traits and Shame to Entrepreneurship
}

\author{
Elifas Gonçalves Juniora
}

\begin{abstract}
The failure of the parent's company has psychological, social, and economic repercussions for the children of these entrepreneurs. Research has identified that the personality traits of conscientiousness and neuroticism are the major influencers of the shame of parental failure among personality traits. The dimensions of openness, extraversion, and agreeableness were not significant. The research is quantitative and cross-sectional. The sample is non-probabilistic and convenient, consisting of literate people from five continents and 33 countries, with a greater predominance of responses from Brazil and Portugal. Data collection on-line was carried out by average social workers, allied to 19 institutions of higher education. The metric used is called the five dimensions of personality-short version. A multiple linear regression was performed to assess the intensity of the five dimensions of personality. Conscientiousness and neuroticism were significant predictors of shame. The results are important to help characterize the children of entrepreneurs who have failed and fill a gap in the literature on entrepreneurship.
\end{abstract}

\section{Keywords}

Shame, entrepreneurship, failure, personality, Big-Five

The failure of organizations represents $25 \%$ of output forms of business activity (McGrath 2006) and can affect human behavior (Ucbasaran et al. 2013). In the event of failure of the company, mental and social processes related to the shame (SHM) of failure may be initiated. One understands failure as the inability of the company to pay off the financial commitments. This study deals with the SHM of failure occurring vicariously, and traits of personality. The objects of study are the children of entrepreneurs who permeated before the failure proceedings of companies created by their parents.

SHM is an instrument of defense or support for life and can shape the ways of proceeding and thinking (Gilbert, Price, and Allan 1995; Leeming 1998; Lewis 1992; Lombardi 2007; Nathanson 1992).
The research aims to answer the following question: What are the personality types that are more susceptible to SHM of the bankruptcy of the parent's company? The study proposes to identify which personality dimensions are most statistically significant in mediating the SHM of parental bankruptcy. Failure and bankruptcy in this paper will be understood as synonyms.

Two metrics were used: Big Five Personality Dimensions (Rammstedt and John 2007) and the TOSCA 3 Test of Self-conscious Affect created by Tangney et al. (2000). The approach is quantitative

aFederal University of Mato Grosso, Brazil

\section{Correspondent Author:}

Elifas Gonçalves Junior, Avenida Italia, 905, Residencial Itália II, Jardim Itália, Cuiabá, Mato Grosso, Brasil 
and the samples are non-probabilistic and convenient (Maroco 2007).

\section{FAILURE}

Ending business activities is common in entrepreneurship. It is illustrated by the Portuguese and Brazilian cases. In Portugal, according to the National Institute of Statistics (2013), 2,306 organizations were constituted and 1,348 or $58.5 \%$ were closed. In the Brazilian case, according to the Brazilian Institute of Geography and Statistics-IBGE (2015), from 2009 to 2013, less than half $(47.5 \%)$ of companies survived after four years of activity. A considerable part of the companies are closed, and failure is the main reason (Baron 2004).

The closure of organizational activities can be considered adequate and rational (Headd 2003). Examples include protecting the assets, extinguishing non-competitive products and services or selling them to other companies (Headd 2003). Discontinuing the activities of the company or other terms of ending or closing the organization, are contrary to the will of the entrepreneur. Among the actions related to the non-voluntary closure of the company, bankruptcy is inserted, understood here as "(...) the cessation of involvement in a venture because it has not met a minimum threshold for economic viability as stipulated by the entrepreneur" (Ucbasaran et al. 2013: 175).

\section{SHAME: THE SILENT EMOTION}

The word shame (SHM) has its origins in the French Teutonic root skam and pre-Teutonic skem, meaning covering or covering oneself (Harper 2011). SHM is an emotion rarely debated in Western society. According to Scheff (1995), it is considered a taboo. For Leeming (1998), regardless of age, one can confess the most intimate secrets, humiliations, rages, and embarrassments, but it is possible that the SHM is kept silent. On the other hand, SHM helps to keep commitments and social order (Leeming and Boyle 2004), motivates behaviors of union and cooperation (Hooge 2011), conserves personal relationships, and avoids situations that damage personal image or future goals (Eynde and Turner 2006).

This secondary emotion arises from the disparity between honor and self-esteem, from right and wrong, and is socially unacceptable (Smith and McElwee 2011). One feels SHM when personal values are put to the test (Bedford and Hwang 2003), and SHM can be experienced or induced by those around us (Leeming and Boyle 2004). SHM is an overwhelming, unpleasant, and painful emotion and goes to the core of the self (Tangney, Stuewig, and Mashek 2007). It is associated with feelings of worthlessness, inferiority, and damaged self-image (Ausubel and Schiff 1955), humiliation (Kaufman 1989), anger, hostility, and revenge (Combs et al. 2010). SHM inhibits social contact (Hooge 2011) and may imply self-condemnation (Eisenberg 2000). SHM can be real or imaginative (Tracy and Robins 2004). People who experience them often are prone to mental disorders such as anxiety, depression (Hooge, Breugelmans, and Zeelenberg 2008; Rüsch et al. 2007), and may be related to feelings and fantasies (Matos and Pinto-Gouveia 2010). SHM is the master emotion of human behavior (Scheff 1995; 2005) and can shape the ways of proceeding and thinking (Tangney et al. 2007).

\section{PERSONALITY}

People can behave in different ways on the same stimulus. One of the elements that compose this interpretive filter is the personality, understood by Martins (2004) as a set of characteristics that guide the way of thinking, acting, and feeling, generally lasting but not unchanging. For Cloninger (2003: 3), personality can be perceived as: "the internal causes 
underlying individual behavior and experience of the person".

The use of personality in the research on entrepreneurship received caveats. Gartner (1985; 1989) may have been the most outspoken critic, concluding that there were so many differences between entrepreneurs and non-entrepreneurs and that behavior rather than personality could better aid entrepreneurship. Other authors have choired Gartner (1985; 1989) such as Low and MacMillan (1998), Shaver and Scott (1991), Robinson et al. (1991), and Aldrich and Wiedenmayer (1993).

Even in the face of criticism, other groups of scientists - to a greater or lesser extent-have imputed that personality influences the propensities to act (Brandstätter 2011; Izard 1993; Krueger, Markon, and Bouchard 2003; Leutner et al. 2014; Rauch and Frese 2007).

It was chosen in this research to identify personality types (PER) in the five dimensions of the personality or Big Five by the simplicity and small number of issues (Brandstätter 2011; Goldberg 1993; Rammstedt and John 2007; Zhao and Seibert 2006), which is briefly described: Openness - personality receptive to events that permeate the new. It carries curiosity and imagination. It is the opposite of a mind that reacts negatively to the unexpected or uncertain. Conscientiousness - personality directed to goals and usually translated with self-discipline. The following are rules and procedures. Plans are planned, arranged, and postponed for future benefits. Extraversion-behavior focused on the socializing. It shows joy and seeks activities in which the group is the main focus. They are considered enthusiastic and have the image of people with enough energy. Agreeableness-a set of characteristics that favor simplicity of living, trust, and concern for others. It has community action and aims for mutual benefits. Tending to believe in people more easily. Neuroticism-denoting poor control of emotions, especially negative ones, and the individual may feel more easily, for example, with symptoms of anxiety, nervousness, and sadness.

In the studies, it is possible that the scale of emotional instability-neuroticism-is the most significant personality trait, as it relates to people with greater sensitivity to react to emotions, especially negative emotions. SHM is considered an example of a reaction to emotional instability. Symptoms of anxiety, nervousness, and sadness are the consequences. Neuroticism is the independent variable and the dependent SHM. In this way, neuroticism will be tested as the PER trait with greater significance for SHM. Thus, the following hypothesis is proposed:

$\mathrm{H}_{1}$ : Neuroticism is the greatest influencer of SHM among the children of failed parents.

It is likely that children of failed parents will be different from the group of children of parents who have not gone bankrupt. Faced with the researched literature, the dimension of neuroticism is one that is associated with emotional disorders. Thus, the hypothesis is proposed:

$\mathrm{H}_{2}$ : Children of failed parents present greater intensity in the neuroticism dimension than children of non-failing parents.

\section{Methods}

There is no known international database that provides the number of failed companies, location, and identification of the children of the failed entrepreneurs. Thus, the snowball technique was used, in which social media were asked to respond to the questionnaire and indicate known acquaintances whose mother, father, or guardian had failed. The other course was characterized by the online submission of the questionnaire to 1,606 Higher Education Institutions (HEI) from 33 countries on five continents. Eleven HEI proposed to submit the questionnaires to the academic community. University students are the main group in the sample. These have less difficulty in contacting 
them, although, people with other schooling and located beyond the HEI gates have contributed. The unit of analysis is individual-level, the child of the failed entrepreneur (Low and MacMillan 1998; Veciana 2007).

\section{Data Collection}

Building up one of the HEI database, the author obtained 257 valid answers and formed the group of children of failed parents. The other group was formed by children of non-bankrupt parents obtaining 1,115 answers. For data collection, a questionnaire was used with closed, yes/no, and multiple choice questions.

The 5-point Likert scale was used, ranging from 1 (completely disagree) to 5 (completely agree). The reasons for the selection of the metrics obeyed the criteria of theoretical proximity of the central problem of research, simplicity, number of items, and public availability without burden to the researcher.

\section{Metrics}

Two metrics were used: one for SHM and one for personality. Below it is described.

Shame. The TOSCA 3 Test of Self-conscious Affect (Tangney et al. 2000) was tested by several authors and validated internationally as a measure of SHM, guilt, and other emotions (Tangney and Dearing 2003). In the short version of TOSCA 3, the positive scenarios were extracted and the pride scale was eliminated (Tangney and Dearing 2003). The initial questionnaire-TOSCA 3-consists of 16 positive and negative scenarios that people are likely to encounter on a day-to-day basis followed by common reactions. Asked to imagine yourself in that situation and indicate the most likely reaction, which in turn is related to: Externalization, Shame, Detached, Guilt, and Pride on a Likert scale ranging from 1 (not likely) to 5 (very likely). The Alpha Cronbach ranged from .86, .77, and .76 for the metric of SHM.

Big Five. Created by Rammstedt and John (2007), the Big Five Inventory short version of the Big Five Inventory (BFI-10) is indicated for participants who have severely limited time. Psychometric characteristics are offered in two items for each personality trait. Big Five had adequate reliability, retest, and validity indexes and was used as one of the metrics.

\section{Sample and Data Collection}

The main group was students from HEI. The students were considered relevant to the study, since they are in a phase of professional choices (Dias and Soares 2012; Peñaloza, Diógenes, and Sousa 2008). They were considered students (Araujo et al. 2010), from middle (Bardagi, Lassance, and Paradiso 2003) and final university course (Teixeira and Gomes 2005).

Recognizing the importance of randomness in statistical samples, when it is not possible to apply it, investigative tools provide an alternative to those that are interested in populations that are not usually available: non-probabilistic samples (Freitas et al. 2000) to represent the population, but it cannot guarantee its reliability (Stevenson 1981; Tavares 2011). However, it is indicated in cases where the population is difficult to access (Field 2009): The children of failed parents here can be fitted.

The data collection occurred between the period from March to April, 2016 and was subdivided into four cycles. In the four weeks, 1,498 nominal e-mails were sent to Rectors, Presidents, Directors, or Chancellors, according to the denomination of each country, in English, Spanish, Portuguese of Brazil, and Portuguese of Portugal. Inserted in body text as image, the response of 11 HEI was obtained.

\section{RESULTS}

\section{Sample Characterization}

The majority of the sample is female (59.4\%). The male respondents are $40.1 \%$. They indicated as "other" 
gender that corresponded to $0.5 \%$ of a total of 1,372 questionnaires answered. Of individuals who participated in the research, $66.6 \%$ are single, $28.5 \%$ are married, $4 \%$ are divorced, and $0.3 \%$ are widowed. The remaining $0.6 \%$ of the sample did not respond to this question.

Regarding the educational level, $69.9 \%$ indicated higher education and $27.8 \%$ referred to graduate. The $2.3 \%$ of participants did not answer the question. The majority of the sample consists of individuals between 16 and 20 years of age (19.5\%), 21 and 25 (28.9\%), and 26 and 30 years (16.9\%). Sample between 16 and 30 years of age constitutes $65.3 \%$. The $8.6 \%$ of the sample are between 31 and 35 years of age, $7 \%$ are between 36 and 40 years of age, $7.2 \%$ are between 41 and $45,5.1 \%$ are between 46 and 50 years, $3.7 \%$ are between 51 and 55 years, $1.7 \%$ are between 56 and 60 years, and only $1.4 \%$ are over 60 years of age.

\section{Personality and Shame}

The following shows the statistically significant and non-significant results for the five dimensions of personality: openness, conscientiousness, extraversion, neuroticism, and agreeableness.

A multiple linear regression was performed to evaluate the intensity of the five dimensions of personality over SHM. The regression equation was found significant $\mathrm{F}(5.251)=8.511, p<.05$, with a $\mathrm{R}^{2}$ of .145 (see Tables 1 and 2).

The SHM is equal to 3.643 to -.124 (extraversion) +.060 (agreeableness) - .233 (conscientiousness) +.294 (neuroticism) - .024 (openness) where SHM and five dimensions of personality (Big Five) are measured on a scale of 1-5 for each internal SHM unit, the intensity of the personality trait extraversion decreases to .124, conscientiousness .233 and .024 for openness and increases the intensity for each internal SHM unit .060 units to .294 units for agreeableness and neuroticism respectively, but only conscientiousness and neuroticism were significant predictors of SHM (see Table 3).
For $p<.05$ with respect to dimensions "conscientiousness" and "neuroticism", it means that both dimensions contribute to SHM. More specifically, and according to the non-standardized coefficients, the effect of "conscientiousness" is negative $(\beta=-.233)$ and the effect of "neuroticism" is positive $(\beta=.294)$. These results corroborate the hypothesis $\mathrm{H}_{1}$ (see Figure 1).

\section{DISCUSSION}

Personality can be posited as a proxy for the singularities of the human being, and was used as an interpretive lens. The model of the five dimensions of personality facilitates the elucidation of differences related to SHM, absorbed by the psyche and translated into the intention to entrepreneur. The personality dimension of neuroticism was significant. People with little control of emotions-especially negative-may be more sensitive to symptoms of psychological disorders such as anxiety and feelings of sadness. SHM (Beta .294) explains $8.1 \%$ of the variation. The results corroborate the following hypotheses: $\mathrm{H}_{1}$-Neuroticism is the major influencer of internal SHM among the children of failing parents and $\mathrm{H}_{2}$ - Children of failed parents present greater intensity in the dimension neuroticism than the children of non-failing parents.

\section{CONCLUSIONS}

Failure is a natural process. Success and failure are not two sides of the coin: the coin itself. Entrepreneurship is a risky activity. If the company goes bankrupt, who generates it fails in the eyes of society. The failure turns into the creator and the body defends itself. The moral emotion of SHM accomplishes this role, most of the time, inhibiting actions in the face of the element of provocation. SHM can be felt by children and causes changes in human behavior. 
Table 1. ANOVA

\begin{tabular}{|c|c|c|c|c|c|c|c|}
\hline \multicolumn{8}{|c|}{ Model sumaryb } \\
\hline Model & $\mathrm{R}$ & \multicolumn{2}{|l|}{ R square } & Adjusted R square & SE of estimate & \multicolumn{2}{|r|}{ Durbin-Watson } \\
\hline 1 & $.381^{\mathrm{a}}$ & .145 & \multicolumn{2}{|l|}{.128} & .83650 & \multicolumn{2}{|r|}{2.000} \\
\hline \multicolumn{8}{|c|}{$\begin{array}{l}\text { Note: a. Predictol } \\
\text { Mean_SHM. }\end{array}$} \\
\hline \multicolumn{8}{|c|}{ Table 2. Model Sumary } \\
\hline \multicolumn{8}{|c|}{ ANOVA $^{\mathrm{a}}$} \\
\hline \multirow[t]{2}{*}{ Model } & & & Sum of squares & $\mathrm{df}$ & Mean square & $\mathrm{F}$ & Sig. \\
\hline & Regre & sion & 29.779 & 5 & 5.956 & 8.511 & $.000^{\mathrm{b}}$ \\
\hline \multirow[t]{2}{*}{1} & Resid & & 175.635 & 251 & .700 & & \\
\hline & Total & & 205.413 & 256 & & & \\
\hline
\end{tabular}

Note: a. Dependent variable: Mean_SHM; b. Predictors: (Constant), Mean_Open, Mean_Extrav, Mean_Neur, Mean_Consc, Mean_Agreab.

Table 3. Unstandardized Coefficients and Standardized Coefficients

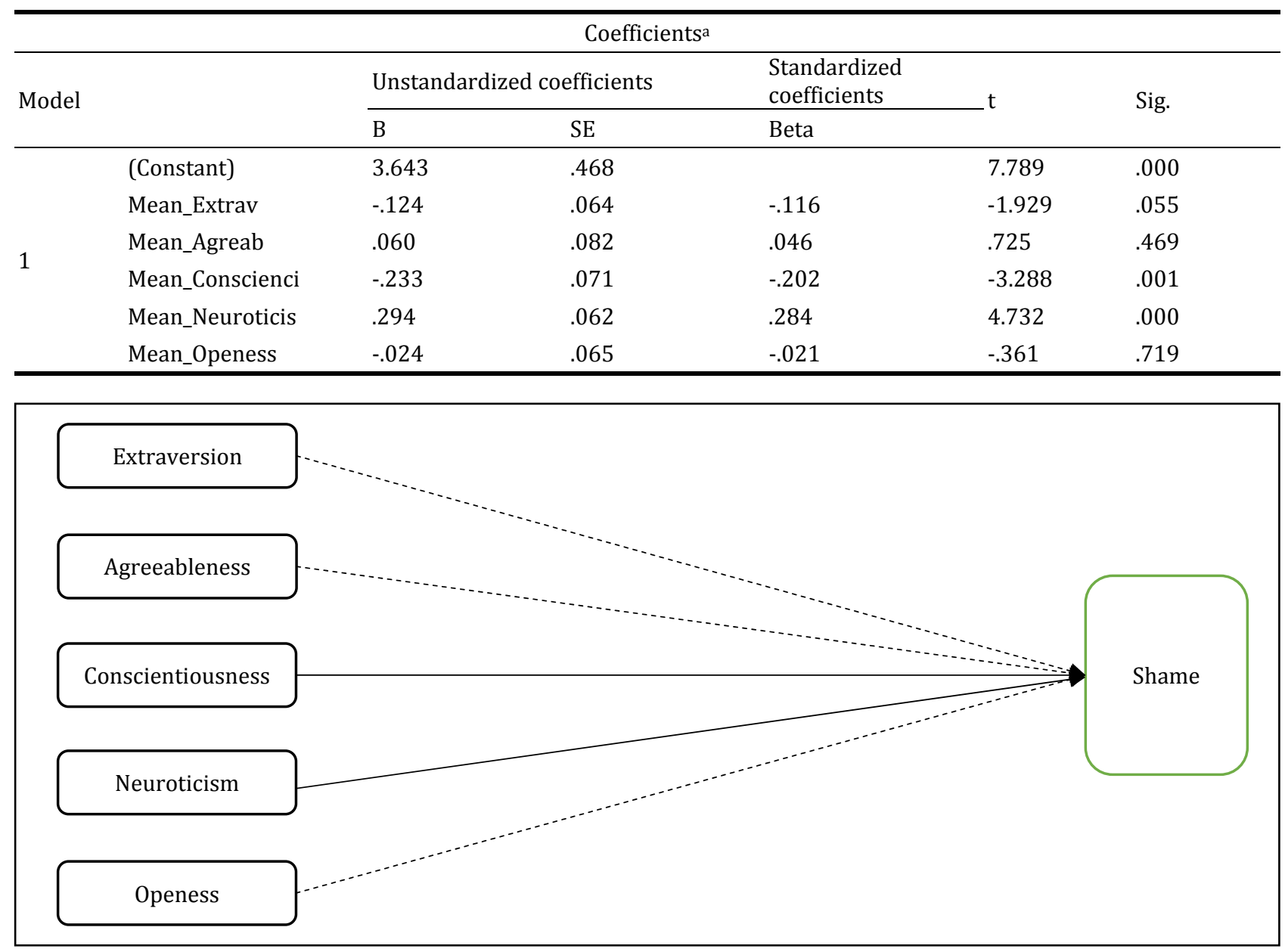

Figure 1. Significant and Non-significant Relationships of Personality Dimensions Related to Shame. Note: -------- = Not statistically significant; $=$ Statistically significant. 


\section{Acknowledgements}

This research was financially supported by the Capes Foundation-Ministry of Education of Brazil. The author also thanked the Portuguese teachers Dr. Ricardo Rodrigues, Dr. Elisabete Sá, and Dr. Vera Carlos.

\section{References}

Aldrich, H. and G. Wiedenmayer. 1993. "From Traits to Rates: An Ecological Perspective on Organizational Foundings." Pp. 145-195 in Advances in Entrepreneurship, Firm Emergence, and Growth, edited by J. Katz and R. Brockhaus. JAI Press.

Araujo, S., J. Boaventura, R. Telles, and J. Siqueira. 2010. "Fatores de escolha da carreira de Administração e da instituição de ensino" (Factors of Career Choice of Administration and Educational Institution). Administração: Ensino E Pesquisa 11(2):163-190.

Ausubel, D. and H. Schiff. 1955. "Some Intrapersonal and Interpersonal Determinants of Individual Differences in Sociempathic Ability Among Adolescents." The Journal of Social Psychology 41(1):39-56.

Bardagi, M., M. Lassance, and A. Paradiso. 2003. "Trajetória acadêmica e satisfação com a escolha profissional de universitários em meio de curso" (Academic Trajectory and Satisfaction With the Professional Choice of University Students in the Middle of the Course). Revista Brasileira de Orientação Profissional 4(1/2):153-166.

Baron, R. 2004. "The Cognitive Perspective: A Valuable Tool for Answering Entrepreneurship's Basic 'Why' Questions.” Journal of Business Venturing 19(2):221-239.

Bateman, T. and M. Crant. 1993. "The Proactive Component of Organizational Behavior: A Measure and Correlates." Journal of Organizational Behavior 14(2):103-118.

Bedford, O. and K. Hwang. 2003. "Guilt and Shame in Chinese Culture: A Cross-Cultural Framework From the Perspective of Morality and Identity." Journal for the Theory of Social Behaviour 2(33):127-144.

Brandstätter, H. 2011. "Personality Aspects of Entrepreneurship: A Look at Five Meta-analyses." Personality and Individual Differences 51(3):222-230.

Cloninger, S. 2003. Teorías de la personalidad (Theories of Personality). 3rd ed. México: Pérson Education.

Combs, D., G. Campbell, M. Jackson, and R. Smith. 2010. "Exploring the Consequences of Humiliating a Moral Transgressor." Basic and Applied Social Psychology 32(2):128-143.

Dias, M. and D. Soares. 2012. "A Escolha profissional no direcionamento da carreira dos universitários" (A Professional Choice in Career Guidance for College Students). Psicologia: Ciência E Profissão 32(2):272-283.

Eisenberg, N. 2000. "Emotion, Regulation and Moral Development." Annu. Rev. Psychol. 51(4):665-697.

Eynde, P. and J. Turner. 2006. "Focusing on the Complexity of Emotion Issues in Academic Learning: A Dynamical Component Systems Approach." Educational Psychology Review 18(4):361-376.

Field, A. 2009. Descobrindo a estatística usando SPSS (Discovering Statistics Using SPSS Statistics). 2nd ed. Porto Alegre: Artmed.

Freitas, H., M. Oliveira, A. Saccol, and J. Moscarola. 2000. "Survey." Revista de Administração 35(3):105-112.

Gartner, W. 1985. "A Conceptual Framework for Describing the Phenomenon of New Venture Creation." The Academy of Management Review 10(4):696-706.

—. 1989. "“Who Is an Entrepreneur?' Is the Wrong Question." Entrepreneurship: Theory and Practice 12(4):47-67.

Gilbert, P., J. Price, and S. Allan. 1995. "Social Comparison, Social Attractiveness and Evolution: How Might They Be Related?" New Ideas in Psychol. 13(2):149-165.

Goldberg, L. 1993. "The Structure of Phenotypic Personality Traits." The American Psychologist 48(1):26-34.

Gottfredson, L. 2002. "Gottfredson's Theory of Circumscription, Compromise, and Self-creation.” P. 555 in Career Choice and Development (4th ed.), edited by B. Duane. San Francisco: Jossey-Bass.

Harper, J. 2011. "Regulating and Coping With Shame." Pp. 189-206 in Reconstructing Emotional Spaces: From Experience to Regulation, edited by R. Trnka, K. Balcar, and M. Kuška. Prague: University of Prague Press.

Headd, B. 2003. "Redefining Business Success: Distinguishing Between Closure and Failure." Small Business Economics 21:51-61.

Hooge, I. 2011. "The General Sociometer Shame: Positive Interpessoal Consequences of an Ugly Emotion." Pp. 95-109 in Psychology of Shame: New Research, edited by K. G. Lockhart. New York: Nova Science Publishers Inc.

Hooge, I., S. Breugelmans, and M. Zeelenberg. 2008. "Not so Ugly After All: When Shame Acts as a Commitment Device." Journal of Personality and Social Psychology 95(4):933-943.

Hutz, C., C. Nunes, A. Silveira, J. Serra, M. Anton, and L. Wieczorek. 1998. "O desenvolvimento de marcadores para a avaliação da personalidade no modelo dos cinco grandes fatores" (The Development of Markers for Personality Assessment in the five Major Factors Model). Psicologia: Reflexão E Crítica 11(2):395-411. 
IBGE—Brazilian Institute of Geography and Statistics. 2015. Enterprise Demography 2013: Less Than Half (47.5\%) of Companies Survive After Four Years of Activity. Retrieved September 7, 2015 (http://saladeimprensa.ibge.gov.br/notic ias? view=noticia\&id=1\&busca=1\&idnoticia=2977).

Izard, C. 1993. "Four Systems for Emotion Activation: Cognitive and Noncognitive Processes." Psychological Review 100(1):68-90.

John, O. and S. Srivastava. 1999. "The Big Five Trait Taxonomy: History, Measurement, and Theoretical Perspectives.” Pp. 102-138 in Handbook of Personality: Theory and Research (vol. 2), edited by L. A. Pervin and O. P. John. New York: Guilford Press.

Johnson, M. and J. Mortimer. 2002. "Career Choice and Development From a Sociological Perspective.” P. 555 in Career Choice and Development (4th ed., vol. 12), edited by D. Brown. San Francisco: Jossey-Bass.

Kaufman, G. 1989. The Psychology of Shame. New York: Springer.

Krueger, R., K. Markon, and T. Bouchard. 2003. "The Extended Genotype: The Heritability of Personality Accounts for the Heritability of Recalled Family Environments in Twins Reared Apart." Journal of Personality 71(5):809, 833.

Leeming, D. 1998. "Shame and Later Life." PSIGE Newsletter 67:17-21.

Leeming, D. and M. Boyle. 2004. "Shame as a Social Phenomenon: A Critical Analysis of the Concept of Dispositional Shame." Psychology and Psychotherapy: Theory Research \& Practice 77(3):375-396.

Leutner, F., G. Ahmetoglu, R. Akhtar, and T. Chamorro-Premuzic. 2014. "The Relationship Between the Entrepreneurial Personality and the Big Five Personality Traits." Personality and Individual Differences 63:58-63.

Lewis, M. 1992. Shame-The Exposed Self. New York: The Free Press.

Lombardi, R. 2007. "Shame in Relation to the Body, Sex, and Death: A Clinical Exploration of the Psychotic Levels of Shame. Psychoanalytic Dialogues 17(3):1-15.

Low, M. and I. MacMillan. 1998. "Entrepreneurship: Past Research and Future Challenges." Journal of Management 14(2): 139 .

Maroco, J. 2007. Statistical Analysis With Use of SPSS. 3rd ed. Lisboa: Silabo.

Martins, L. 2004. "The Social-Historical Nature of Personality." Cadernos CEDES 24(62):82-99.

Matos, M. and J. Pinto-Gouveia. 2010. "Shame as a Traumatic Memory." Clinical Psychology and Psychotherapy 17(4):299-312.

McGrath, R. 2006. "Rumors of My Mortality Have Been Greatly Exaggerated: Reconsidering the Mortality
Hypothesis." Academy of Management, Atlanta, GA.

Nathanson, D. 1992. Shame and Pride: Affect, Sex, and the Birth of the Self. New York: W. W. Norton \& Company.

National Institute of Statistics. 2013. Constitution and Dissolution of Legal Persons and Entities Treated as Such (No) by Geographic Location (NUTS-2013) and Economic Activity (CAE Rev. 3). Monthly_Portugal-Last update 08/31/2016. INEP. Lisbon. Retrieved (https://www.ine.pt/ xportal/xmain?xpid=INE\&xpgid=ine_indicadores\&indOcor $\mathrm{rCod}=0008068 \&$ contexto $=$ bd\&selTab=tab2).

Peñaloza, V., C. Diógenes, and S. Sousa. 2008. "Escolha profissional no curso de administração: tendências empreendedoras e gênero" (Professional Choice in the Administration Course: Entrepreneurial Tendencies and Gender). RAM. Revista de Administração Mackenzie 9(8):151-167.

Rammstedt, B. and O. John. 2007. "Measuring Personality in One Minute or Less: A 10-item Short Version of the Big Five Inventory in English and German." Journal of Research in Personality 41(1):203-212.

Rauch, A. and M. Frese. 2007. "Let's Put the Person Back Into Entrepreneurship Research: A Meta-analysis on the Relationship Between Business Owners' Personality Traits, Business Creation, and Success." European Journal of Work and Organizational Psychology 16(4):353-385.

Robinson, P., D. Stimpson, J. Huefner, and H. Hunt. 1991. "An Attitude Approach to the Prediction of Entrepreneurship." Entrepreneurship: Theory \& Practice 15(4):13-31.

Rüsch, N., P. Corrigan, M. Bohus, G. Jacob, R. Brueck, and K. Lieb. 2007. "Measuring Shame and Guilt by Self-report Questionnaires: A Validation Study." Psychiatry Research 150(3):313-325.

Scheff, T. 1995. "Shame and Related Emotions: An Overview." American Behavioural Scientist 38:1053-1059.

- 2005. When Shame Gets out of Hand. Retrieved (http://www.corwin.com/upm-data/13294_Chapter_5_Web _Byte_Thomas_J_Scheff.pdf).

Shaver, K. and L. Scott. 1991. "Person, Process, Choice: The Psychology of New Venture Creation." Entrepreneurship Theory and Practice 16(2):23-45.

Smith, R. and G. McElwee. 2011. "After the Fall: Developing a Conceptual Script-Based Model of Shame in Narratives of Entrepreneurs in Crisis!" International Journal of Sociology and Social Policy 31(1/2):91-109.

Stevenson, W. 1981. "Amostragem" (Sampling). P. 495 in Estatística aplicada à administração (Statistics Applied to the Administration), edited by W. J. Stevenson. São Paulo: Harper \& Haw do Brasil.

Tangney, J. and K. Fischer. 1995. Self-conscious Emotions: The Psychology of Shame, Guilt, Embarrassment, and Pride. New York, NY: Guilford Press. 
Tangney, J. and R. Dearing. 2003. Shame and Guilt. IGARSS 2014. New York: The Guilford Press.

Tangney, J., J. Stuewig, and D. Mashek. 2007. "Moral Emotions and Moral Behaviour.” Annu Rev Psychol 58:345-372.

Tangney, J., R. Dearing, P. Wagner, and R. Gramzow. 2000. "Test of Self-conscious Affect-3 (TOSCA 3)." In Shame and Guilt, edited by J. P. Tangney and R. L. Dearing. New York: Guilford Press.

Tangney, J., R. Miller, L. Flicker, and D. Barlow. 1996. "Are Shame, Guilt, and Embarrassment Distinct Emotions?" Journal of Personality and Social Psychology 70(6):1256-1269.

Tavares, M. 2011. Estatística aplicada à administração (Statistics Applied to the Administration). Brasilia: CAPES/UAB.

Teixeira, M. and W. Gomes. 2005. "Decisão de carreira entre estudantes em fim de curso universitário" (Career Decision Among Undergraduate Students). Psicologia: Teoria E Pesquisa 21(3):327-334.

Tracy, J. and R. Robins. 2004. "Keeping the Self in Self-conscious Emotions: Further Arguments for a
Theoretical Model.” Psychological Inquiry 15(2):171-177. Ucbasaran, D., D. Shepherd, A. Lockett, and S. Lyon. 2013. "Life After Business Failure: The Process and Consequences of Business Failure for Entrepreneurs." Journal of Management 39(1):163-202.

Veciana, J. 2007. "Entrepreneurship as Scientific Research Program.” P. 348 in Entrepreneurship: conceptos, teoria y perspectiva (Entrepreneurship: Concepts, Theory and Perspective), edited by A. Cuervo, D. Ribeiro, and S. Rigi. New York: Springer.

Zhao, H. and S. Seibert. 2006. "The Big Five Personality Dimensions and Entrepreneurial Status: A Meta-analytical Review." The Journal of Applied Psychology 91(2):259-271.

\section{Bio}

Elifas Gonçalves Junior, Ph.D., professor, Federal University of Mato Grosso, Brazil; research fields: entrepreneurship and business administration. 